Published by Al-Nahrain College of Medicine P-ISSN 1681-6579

E-ISSN 2224-4719

Email: iraqijms@colmed-alnahrain.edu.iq

http://www.colmed-alnahrain.edu.iq

http://www.iraqijms.net

Iraqi JMS 2019; Vol. 17(2)

\title{
Reproductive Hormonal Assay of a Sample of Iraqi Obese Males
}

\author{
Imad M. Abdul-Rahman ${ }^{1}$ MSc, Atheer J. Abdul-Ameer ${ }^{2}$ FICMS \\ ${ }^{1}$ Public Health Unit, Al-Imamein Al-Kadhimein Medical City, Baghdad, Iraq, ${ }^{2}$ Dept. of Family and Community Medicine, \\ College of Medicine, Al-Nahrain University, Baghdad, Iraq.
}

\begin{abstract}
Background The World Health Organization considered obesity as a medical condition that may lead to reduced life expectancy and/or increased health problems. While much of the focus on the impairments caused by obesity is on somatic health, recent data suggest that reproductive health may also be impacted.

Objective To quantify the relation between obesity and the reproductive hormones.

Methods This cross-sectional study was carried out at nutrition clinic in three teaching hospitals and one obesity clinic in a medical college in Baghdad. The body mass index (BMI) calculation, blood sugar, serum cholesterol, triglyceride, testosterone, prolactin, follicular stimulating hormone (FSH), and luteinizing hormone (LH) were measured.

Results Ninety-five adult obese males participated in this study. Serum testosterone had significant negative correlation with BMI, weight, serum cholesterol, and serum triglyceride while serum $\mathrm{LH}$ had significant positive correlation with BMI ( $p$ value was 0.013 ), weight ( $p$ value was 0.027 ), and serum triglyceride ( $p$ value was 0.049).

Conclusion

Male obesity has significant effect on serum level of testosterone and $\mathrm{LH}$.

Keywords Obesity, reproductive hormones

Citation

Abdul-Rahman IM., Abdul-Ameer AJ. Reproductive hormonal assay of a sample of Iraqi obese males. Iraqi JMS. 2019; 17(2): 114-119. doi: 10.22578/IJMS.17.2.4
\end{abstract}

List of abbreviations: $\mathrm{BMI}=$ Body mass index, $\mathrm{FPG}=$ Fasting plasma glucose, $\mathrm{FSH}=$ Follicular stimulating hormone, $\mathrm{LH}=$ Luteinizing hormone, $\mathrm{PRL}=$ Prolactin, $\mathrm{S} . \mathrm{Chol}=$ Serum cholesterol, S.TG $=$ Serum triglyceride, $\mathrm{T}=$ Testosterone

\section{Introduction}

$\mathrm{T}$ he obesity epidemic is a growing public health concern. Indeed, the American Medical Association classified obesity as a disease ${ }^{(1)}$. Previously, much of the focus on the impairments caused by obesity was on somatic health but the recent data suggested that reproductive health may also be impacted (2). Obesity can influence the normal concentrations of male sex hormones at different levels in form of reduced central production and an increased peripheral degradation ${ }^{(3,4)}$. The reproductive hormonal profiles of most obese men deviate from what is considered to be normal levels. Obese men tend to present with elevated estrogen and low testosterone $(T)$ and follicular stimulating hormone (FSH) levels (3). Obese men exhibit decreased levels of total $T$ and increased estrogens levels. Decreased $\mathrm{T}$ and T/estrogen ratios have been documented among infertile obese men compared with infertile non-obese men and fertile obese men ${ }^{(5)}$. Grossly obese men may show an unequivocal reduction of free $T$ levels, where luteinizing hormone (LH) and FSH levels are usually low or inappropriately normal, suggesting that the dominant suppression occurs at the hypothalamic- 
pituitary level ${ }^{6}$ ). Several reports showed that obese men exhibit significant decrease in androgen level, which was correlated with the degree of obesity ${ }^{(6,7)}$. It has been shown that body mass index (BMI) was positively related to estradiol levels and inversely related to total $T$ level ${ }^{(8)}$. There was also a strong inverse relation between $\mathrm{BMI}$ and a lower $\mathrm{T} / \mathrm{LH}$ ratio among men with a $\mathrm{BMI} \geq 35 \mathrm{~kg} / \mathrm{m}^{2}$ (9).

The effects of increased BMI in Iraqi men on the reproductive hormones level have not been subjected to the same degree of research as Iraqi females. Therefore, this study was designed to assess the pattern of reproductive hormones among obese males, specifically: ( $T$, prolactin ( $\mathrm{PRL}), \mathrm{FSH}, \mathrm{LH}$ ) and to investigate the correlations between obesity and the reproductive hormones.

\section{Methods}

A cross-sectional study was carried out at nutrition clinic in three teaching hospitals in Baghdad (Al-Imamein Al-Kadhimein Medical City, Al-Kindy Teaching Hospital and Al-Yarmouk Teaching Hospital) and at Obesity Clinic in AlKindy Medical College for the period from $20^{\text {th }}$ of February 2016 till $5^{\text {th }}$ of July 2017. All adult males who visited the clinics for obesity were asked to participate in the study. Consecutive sampling was used to collect the sample after taking their informed consent.

Ninety-five adult males (18 to 65 years of age) with $\mathrm{BMI}$ of greater than or equal to 30 were included. Those with history of hypertension or on antihypertensive drugs, those who were previously diagnosed to be aspermic or azoospermic, and/or those who were diagnosed to have endocrine diseases or on treatment for these diseases were excluded from the study. Socio-demographic characteristics of each participant were obtained, focusing on age, residency (rural or urban), marital status (single, married, widow, or divorced), occupation (type of occupation), and smoking (current and exsmoking). Physical examination was done to all participants stressing on height and weight measurements (to calculate the $\mathrm{BMI}$ ), and blood pressure measurement were done. The weight was measured (to nearest $0.5 \mathrm{Kg}$ ), in erect position without shoes, coats, or overalls with an electronic scale. Height was measured by using tape height measure which is suitable to measure a person's height with an approximation of $\pm 1 \mathrm{~mm}$. BMI was calculated as body weight $/ \mathrm{height}^{2}\left(\mathrm{Kg} / \mathrm{m}^{2}\right)$. Participants were classified as class 1 obesity if their BMI is (30$34.9 \mathrm{~kg} / \mathrm{m}^{2}$ ), class 2 obesity if their BMI is (35$\left.39.9 \mathrm{~kg} / \mathrm{m}^{2}\right)$, and class 3 obesity if their BMI is (40 kg/m ${ }^{2}$ or more) ${ }^{(10)}$. Blood pressure was measured using mercury sphygmomanometer in sitting position.

Venous blood samples were withdrawn from each participant and sent for fasting plasma glucose (FPG), serum cholesterol (S.Chol), serum triglyceride (S.TG), serum $T$, serum PRL, serum FSH, and serum LH. Participant was considered diabetic if his FPG $\geq 7.0 \mathrm{mmol} / \mathrm{I}^{\text {(11). }}$. $\mathrm{S}$.Chol was considered of desirable level when it was $<200 \mathrm{mg} / \mathrm{dl}$, borderline high when it was 200-239 mg/dl, and high when it was $\geq 240$ $\mathrm{mg} / \mathrm{dl}$. S.TG was considered normal when it was $<150 \mathrm{mg} / \mathrm{dl}$, borderline high when it was 150$199 \mathrm{mg} / \mathrm{dl}$, and high when it was $\geq 200 \mathrm{mg} / \mathrm{dl}^{(12)}$. Normal ranges for the reproductive hormones were considered as follows: serum $\mathrm{T}(2.8-11$ $\mathrm{ng} / \mathrm{ml})$, serum PRL $(2.5-15 \mathrm{ng} / \mathrm{ml})$, serum FSH $(1.4-15.4 \mathrm{mIU} / \mathrm{ml})$, and serum LH $(1.24-7.8$ $\mathrm{mIU} / \mathrm{ml})^{(13)}$.

Data entered and analyzed using SPSS (Statistical Packages for Social Sciences) program, version 18. Descriptive data were expressed as means and standard deviations for continuous measurements and as frequencies and percentages for categorical measurements. Differences of Reproductive hormones according to obesity classes were compared using analysis of variance (ANOVA) test. Relationships between reproductive hormones and obesity parameters were studied by Pearson correlation test. $\mathrm{P}<0.05$ was set as statistically significant.

\section{Results}

Ninety-five obese men participated in this study with mean $( \pm S D)$ BMI was $(39.23 \pm 4.41) \mathrm{kg} / \mathrm{m}^{2}$. One fifth of them (20\%) were of class 1 obesity, 
$43(45.3 \%)$ were of class 2 , and $33(34.7 \%)$ were of class 3 obesity.
Socio-demographic, clinical, and laboratory characteristics of the participants were shown in table 1.

Table 1. Socio-demographic, clinical, and laboratory characteristics of the participants

\begin{tabular}{|c|c|c|c|}
\hline \multicolumn{2}{|c|}{ Variable } & No & $\%$ \\
\hline Age (years) $\mathrm{M}$ & SD (Range) & \multicolumn{2}{|c|}{$32.62 \pm 7.02(21-46)$} \\
\hline \multirow{2}{*}{ Residency } & Rural & 7 & 7.4 \\
\hline & Urban & 88 & 92.6 \\
\hline \multirow{2}{*}{ Marital Status } & Single & 43 & 45.3 \\
\hline & Married & 52 & 54.7 \\
\hline \multirow{3}{*}{ Occupation } & Employed & 30 & 31.6 \\
\hline & Unemployed & 54 & 56.8 \\
\hline & Student & 11 & 11.6 \\
\hline \multirow{3}{*}{ Smoking } & Current & 36 & 37.9 \\
\hline & Ex & 18 & 18.9 \\
\hline & Never & 41 & 43.2 \\
\hline \multirow{2}{*}{ Diabetes } & Yes & 18 & 18.9 \\
\hline & No & 77 & 81.1 \\
\hline \multirow{4}{*}{ Cholesterol (mg/dl) } & (Mean \pm SD) & \multicolumn{2}{|c|}{$265.83 \pm 85.59$} \\
\hline & High & 60 & 63.2 \\
\hline & Borderline & 4 & 4.2 \\
\hline & Normal & 31 & 32.6 \\
\hline \multirow{4}{*}{ Triglyceride (mg/dl) } & (Mean \pm SD) & \multicolumn{2}{|c|}{$275.35 \pm 92.05$} \\
\hline & High & 68 & 71.6 \\
\hline & Borderline & 16 & 16.8 \\
\hline & Normal & 11 & 11.6 \\
\hline \multirow{3}{*}{ Testosterone (ng/ml) } & (Mean \pm SD) & \multicolumn{2}{|c|}{$2.83 \pm 2.13$} \\
\hline & Normal & 25 & 26.3 \\
\hline & Low & 70 & 73.7 \\
\hline \multirow{4}{*}{ Prolactin (ng/ml) } & (Mean \pm SD) & \multicolumn{2}{|c|}{$13.65 \pm 7.47$} \\
\hline & High & 7 & 7.4 \\
\hline & Normal & 79 & 83.1 \\
\hline & Low & 9 & 9.5 \\
\hline \multirow{2}{*}{ FSH (mlU/ml) } & (Mean \pm SD) & \multicolumn{2}{|c|}{$4.69 \pm 2.28$} \\
\hline & Normal & 95 & 100 \\
\hline \multirow{3}{*}{ LH (mlU/ml) } & (Mean \pm SD) & \multicolumn{2}{|c|}{$3.61 \pm 1.52$} \\
\hline & High & 2 & 2.1 \\
\hline & Normal & 93 & 97.9 \\
\hline
\end{tabular}

There was a significant difference in the mean of T, FSH, LH among different classes of obesity ( $p$ value $<0.05$ ) while no significant difference in the mean of PRL ( $p$ value $>0.05$ ) as shown in table 2.

The BMI, body weight, and S.TG had significant negative correlation with $T$, significant positive correlation with $\mathrm{LH}$, nonsignificant correlation with PRL, and nonsignificant correlation with FSH. S.Chol had significant negative correlation with $\mathrm{T}$, nonsignificant correlation with $\mathrm{PRL}$, and nonsignificant correlation with $\mathrm{FSH}$ and $\mathrm{LH}$ as shown in table 3.

\section{6}


Iraqi JMS 2019; Vol. 17(2)

Table 2. Differences of Reproductive hormones according to obesity classes

\begin{tabular}{|c|c|c|c|c|c|}
\hline Hormones & $\begin{array}{l}\text { Obesity } \\
\text { Class } 1\end{array}$ & $\begin{array}{c}\text { Obesity } \\
\text { Class } 2\end{array}$ & $\begin{array}{c}\text { Obesity } \\
\text { Class } 3\end{array}$ & $\mathbf{F}$ & $\begin{array}{c}P \\
\text { value }\end{array}$ \\
\hline Testosterone (ng/ml) (Mean \pm SD) & $3.33 \pm 2.40$ & $3.18 \pm 2.15$ & $2.08 \pm 1.78$ & 3.27 & 0.042 \\
\hline Prolactin (ng/ml) (Mean士SD) & $15.71 \pm 7.15$ & $13.38 \pm 7.0$ & $12.81 \pm 8.2$ & 0.96 & 0.387 \\
\hline FSH (mlU/ml) (Mean \pm SD) & $3.50 \pm 1.15$ & $5.32 \pm 2.22$ & $4.56 \pm 2.58$ & 4.64 & 0.012 \\
\hline LH (mlU/ml) (Mean士SD) & $2.37 \pm 0.53$ & $4.21 \pm 1.65$ & $3.56 \pm 1.44$ & 11.76 & 0.000 \\
\hline
\end{tabular}

Table 3. Correlation of reproductive hormones with obesity parameters ( $r$, P value)

\begin{tabular}{ccccc}
\hline & Testosterone & Prolactin & FSH & LH \\
\hline BMI & $-0.316,(0.002)$ & $-0.046,(0.661)$ & $0.172,(0.096)$ & $0.253,(0.013)$ \\
Weight & $-0.292,(0.004)$ & $-0.010,(0.924)$ & $0.154,(0.135)$ & $0.227,(0.027)$ \\
Cholesterol & $-0.209,(0.042)$ & $-0.110,(0.289)$ & $0.066,(0.525)$ & $0.134,(0.195)$ \\
Triglyceride & $-0.235,(0.022)$ & $-0.082,(0.428)$ & $0.065,(0.529)$ & $0.203,(0.049)$ \\
\hline
\end{tabular}

( $P$ values between parentheses)

\section{Discussion}

There was scarcity of previous studies about the prevalence of obesity among Iraqi people. However, WHO had estimated that the prevalence of obesity among adult Iraqi people in 2008 to be $29 \%$. The prevalence of obesity among females was $36 \%$ while among males was $22 \%$. In 2014 , the prevalence among females was $14.9 \%$ and among males was $10.8 \%$ (14). The Iraqi Ministry of Health, in association with WHO, declared in 2015 that the prevalence of obesity among adult Iraqi people became $33.5 \%$. The prevalence among females was $42.6 \%$ and among males was $25.6 \%$ (15).

The mean age group of participants in this study was 32.62 years, $92.6 \%$ of them were from urban area, $54.7 \%$ were married and the rest were single. More than half of them $56.4 \%$ were unemployed, and $37.9 \%$ of them were currently smokers. Owing to the scarcity of literature on this subject we were unable to compare these socio-demographic characteristics with other studies.

The present study showed also that there were significant differences in the mean level of $\mathrm{T}$, $\mathrm{FSH}$, and $\mathrm{LH}$ among the different classes of obesity. It is previously known that obesity has a negative influence on the level of $T{ }^{(16)}$. A significant negative correlation between BMI and $\mathrm{T}$ was demonstrated in this study. It has been proposed that obesity may lead to suppression of hypothalamic pituitary function and inhibit the production of FSH and $\mathrm{LH}$, thereby resulting in reduced testicular function and testosterone production and lower levels of intratesticular and circulating testosterone; Zohdy et al. found a significant negative correlation between $\mathrm{BMI}$ and serum total $\mathrm{T}^{(17)}$. Also, the researchers from Reproductive Biology Associates reported that high BMI in men is correlated with reduced testosterone levels ${ }^{(18)}$. Al-Hameid et al. showed that obesity is associated with a significant decrease in T level (19). Glass et al. reported significant negative correlations between total serum $\mathrm{T}$ and percentage ideal body weight, and normal level of serum $\mathrm{LH}$ and FSH among the obese subjects (20).

This study showed also that there was a significant positive correlation between BMI and $\mathrm{LH}$ level and non-significant correlation between BMI and FSH. Hofny et al. had also reported that $\mathrm{BMI}$ had a significant positive correlation with $\mathrm{LH}$ and a non-significant correlation with serum FSH in obese infertile males compared with obese fertile males ${ }^{(21)}$. AlHameid et al. also found that obesity is associated with a significant increase in serum $\mathrm{LH}$ and FSH levels (19). While, Jensen et al. 
reported that $\mathrm{BMI}$ had no effect on serum $\mathrm{FSH}$ or LH in men ${ }^{(22)}$.

The association between $\mathrm{BMI}$ and serum PRL level was also investigated in the present study. It was found that serum PRL level was nonsignificantly correlated with the BMI. Although the increased body weight may be associated with prolactinoma and that weight loss occurred with normalization of prolactin levels. A Nigerian study had found non-significant associations between $\mathrm{BMI}$ and serum levels of PRL, T, or LH ${ }^{(23)}$.

A significant negative correlation between serum T level and both serum TG and chol levels was demonstrated in this study. Also, a significant positive correlation between serum LH and serum TG level but non-significant correlation between serum TG and FSH and prolactin were found. Adipose tissue is one of the tissues where conversion of androgens to estrogens took place, therefore, obese men usually have increased estrogen levels which inhibit the production of FSH and LH. Hagiuda et al. found a negative association between serum testosterone levels and serum TG levels and no significant association between the TG and $\mathrm{LH}$ or FSH levels (24).

In conclusion, the association found between $\mathrm{BMI}$ and some reproductive hormones may be of help to broaden the understanding of the effect of obesity on male reproductive physiologic characteristics since this study showed that there was significant negative correlation between $\mathrm{BMI}$ and serum $\mathrm{T}$ and significant positive correlation between BMI and serum $\mathrm{LH}$.

\section{Acknowledgement}

Authors thank all the staff of Al-Imamein AlKadhimein Medical City, Al-Kindy Teaching Hospital, Al-Yarmouk Teaching Hospital and the Obesity Clinic in Al-Kindy Medical College for their support and great work in this study.

\section{Author contribution}

Dr. Abdul-Rahman: Collection of study cases, performing and doing the tests of the research. Dr. Abdul-Ameer: Interpretation the results done under her supervision.
Conflict of interest

None declared.

Funding

None.

\section{References}

1. Allison DB, Downey $M$, Atkinson RL, et al. Obesity as a disease: a white paper on evidence and arguments commissioned by the Council of The Obesity Society. Obesity (Silver Spring). 2008; 16(6): 1161-77. doi: 10.1038/oby.2008.231.

2. Eisenberg ML, Kim S, Chen Z, et al. The relationship between male BMI and waist circumference on semen quality: Data from the LIFE study. Hum Reprod. 2014; 29(2): 193-200. doi: 10.1093/humrep/det428.

3. Cabler $S$, Agarwal $A$, Flint $M$, et al. Obesity: modern man's fertility nemesis. Asian J Androl. 2010; 12(4): 480-9. doi: 10.1038/aja.2010.38.

4. Rao SR, Kini S, Tamler R. Sex hormones and bariatric surgery in men. Gend Med. 2011; 8(5): 300-11. doi: 10.1016/j.genm.2011.05.007.

5. Pauli EM, Legro RS, Demers LM, et al. Diminished paternity and gonadal function with increasing obesity in men. Fertil Steril. 2008; 90(2): 346-51. doi: 10.1016/j.fertnstert.2007.06.046.

6. Hammoud AO, Wilde N, Gibson M, et al. Male obesity and alteration in sperm parameters. Fertil Steril. 2008; 90(6): 2222-5. doi: 10.1016/j.fertnstert.2007.10.011.

7. Magnusdottir EV, Thorsteinsson $T$, Thorsteinsdottir $S$, et al. Persistent organochlorines, sedentary occupation, obesity and human male subfertility. Hum Reprod. 2005; 20(1): 208-15. doi: 10.1093/humrep/deh569.

8. Chavarro JE, Toth TL, Wright DL, et al. Body mass index in relation to semen quality, sperm DNA integrity, and serum reproductive hormone levels among men attending an infertility clinic. Fertil Steril. 2010; 93(7): 2222-31. doi: 10.1016/j.fertnstert.2009.01.100.

9. Derby CA, Zilber S, Brambilla D, et al. Body mass index, waist circumference and waist to hip ratio and change in sex steroid hormones: the Massachusetts Male Ageing Study. Clin Endocrinol (Oxf). 2006; 65(3): 12531. doi: 10.1111/j.1365-2265.2006.02560.x.

10. WHO. Obesity: preventing and managing the global epidemic. Report of a WHO Consultation (WHO Technical Report Series 894). 2000. Available from: http://www.who.int/nutrition/publications/obesity/ WHO_TRS_894/en/. Accessed on: 21 December 2017.

11. Canadian Diabetes Association Clinical Practice Guidelines Expert Committee, Goldenberg R, Punthakee Z. Definition, classification and diagnosis of diabetes, prediabetes and metabolic syndrome. Can J Diabetes. 2013; 37 Suppl 1: S8-11. doi: 10.1016/j.jcjd.2013.01.011.

12. Nirosha K, Divya $M$, Vamsi $S$, et al. A review on hyperlipidemia. IJNTPS. 2014; 4(5): 81-92. 
13. Burtis CA, Ashwood ER. Tietz Textbook of clinical chemistry. $3^{\text {rd }}$ ed. Philadelphia: WB Saunders; 1998.

14. Iraq human development report 2014. Available from: http://www.globalnutritionreport.org/files/2014/11/ gnr14_cp_iraq.pdf. Accessed on: 21 December 2017.

15. Iraqi $\mathrm{MOH}$ and WHO. Symposium for launching the results of the national non communicable diseases risk factors survey. 2016 ((Special Connection)).

16. Pasquali R. Obesity and androgens: facts and perspectives. Fertil Steril. 2006; 85(5): 1319-40. doi: 10.1016/j.fertnstert.2005.10.054.

17. ZohdyW, Kamal EE, Ibrahim Y. Androgen deficiency and abnormal penile duplex parameters in obese men with erectile dysfunction. J Sex Med. 2007; 4(3): 797808. doi: 10.1111/j.1743-6109.2007.00499.x.

18. Roth MY, Amory JK, Page ST. Treatment of male infertility secondary to morbid obesity. Nat Clin Pract Endocrinol Metab. 2008; 4(7): 415-9. doi: 10.1038/ncpendmet0844.

19. Al-Hameid SA, Zabbon AA, Saeed NAAAH. Effect of obesity on some reproductive hormones in Iraqi men. J Genet Environ Resour Conserv. 2014; 2(1): 103-6.

20. Glass AR, Swerdloff RS, Bray GA, et al. Low Serum Testosterone and Sex-Hormone-Binding-Globulin in Massively Obese Men. J Clin Endocrinol Metab. 1977; 45(6): 1211-9. DOI: 10.1210/jcem-45-6-1211.
21. Hofny ER, Ali ME, Abdel-Hafez HZ, et al. Semen parameters and hormonal profile in obese fertile and infertile males. Fertil Steril. 2010; 94(2): 581-4. doi: 10.1016/j.fertnstert.2009.03.085.

22. Jensen TK, Andersson AM, Jørgensen N, et al. Body mass index in relation to semen quality and reproductive hormones among 1,558 Danish men. Fertil Steril. 2004; 82(4): 863-70. doi: 10.1016/j.fertnstert.2004.03.056.

23. Egwurugwu JN, Nwafor A, Chike CP, et al. The relationship between body mass index, semen and sex hormones in adult male. Niger J Physiol Sci. 2011; 26(1): 29-34.

24. Hagiuda J, Ishikawa H, Furuuchi $T$, et al. Relationship between dyslipidaemia and semen quality and serum sex hormone levels: An infertility study of 167 Japanese patients. Andrologia. 2014; 46(2): 131-5. doi: 10.1111/and.12057.

Correspondence to Dr. Imad M. AbdulRahman

E-mail: dr_imad72@yahoo.com

Received Feb. $1^{\text {st }} 2018$

Accepted May $6^{\text {th }} 2018$ 